\title{
ESTIMASI PENDAPATAN DAN TINGKAT KERENTANAN PENGHIDUPAN NELAYAN DALAM MENGHADAPI VARIABILITAS MUSIM DI KABUPATEN LUMAJANG
}

\author{
Income Estimation and Fishers Livelihood Vulnerability in Facing \\ Season Variability in Lumajang District
}

\author{
*Indah Fitriani, Asri Sawiji, Noverma \\ Universitas Islam Negeri Sunan Ampel Surabaya \\ Jl. Ahmad Yani No.117, Jemur Wonosari, Kec. Wonocolo, Kota SBY, Jawa Timur 60237 \\ Diterima tanggal: 29 September 2019 Diterima setelah perbaikan: 2 Oktober 2020 \\ Disetujui terbit: 20 Desember 2020
}

\begin{abstract}
ABSTRAK
Perubahan musim mengakibatkan terjadinya pola pergeseran musim barat ataupun timur dan kondisi perairan laut yang tidak dapat diprediksi. Hal ini menyebabkan jumlah hari melaut menjadi tidak menentu yang mempengaruhi besaran pendapatan nelayan. Penelitian ini bertujuan untuk mengestimasi besar pendapatan kelompok nelayan di Pantai Dampar, Kabupaten Lumajang saat musim timur dan barat, menganalisis faktor-faktor yang mempengaruhi, serta tingkat kerentanan penghidupan nelayan dalam menghadapi variabilitas musim. Jumlah sampel penelitian sebanyak 66 orang dari total 78 orang nelayan di Pantai Dampar yang tergabung dalam Kelompok Usaha Bersama Nelayan (KUBN Dampar). Analisis untuk mengetahui besar pendapatan kelompok nelayan diperoleh dari selisih antara penerimaan total dengan total biaya operasional. Selanjutnya, analisis faktor penentu dilakukan menggunakan analisis regresi linear berganda menggunakan SPSS versi 25, sedangkan terkait tingkat kerentanan dianalisis menggunakan metode Livelihood Vulnerability Index (LVI). Hasil analisis menunjukkan bahwa pendapatan nelayan pada musim timur lebih tinggi dibandingkan musim barat. Persentase selisih pendapatan nelayan pada musim timur dibandingkan pada musim barat sebesar $34 \%$ pada kelompok nelayan pancing, $14 \%$ pada kelompok nelayan jaring dan $16 \%$ pada kelompok nelayan pancing dan jaring. Adapun faktor-faktor yang mempengaruhi meliputi: jumlah hari melaut, jarak tempuh, kedalaman, lama melaut, pengalaman, tinggi gelombang, angin dan hujan. Namun lama melaut mempunyai pengaruh paling besar dengan persentase $36,5 \%$. Hasil analisis LVI menunjukkan bahwa tingkat kerentanan untuk semua kelompok nelayan masuk dalam ketegori rentan dengan skala LVI sebesar 0,28 sampai 0,31. Berdasarkan hasil penelitian menunjukkan bahwa semakin tinggi skala $\mathrm{LVI}$, maka kelompok nelayan semakin rentan terhadap variabilitas musim, sehingga pendapatan yang diperolehnya lebih sedikit jika dibandingkan dengan kelompok nelayan lainnya. Penilaian pada lima modal yakni modal sosial, ekonomi, manusia, fisik, dan alam masih perlu dilakukan guna mendukung tingkat resiliensi atau kelompok nelayan.
\end{abstract}

Kata Kunci: Variabilitas musim, indeks kerentanan, pendapatan, kelompok nelayan

\section{ABSTRACT}

Season change results in shifting patterns of west or east monsoons and unpredictable marine conditions. This causes days of fishing become uncertain that may affect income of fishers. This study aims to determine the income of fishers in Dampar Beach, Lumajang Regency during east and west seasons and determine the vulnerability index of fishers's livelihood in facing season variability. Research was conducted on 66 members of fishers joint venture group in Dampar Beach (KUBN Dampar). Determining income of the fishers group is obtained from the subtraction of total fishing revenue with total operating costs. Furthermore, determinant factors were analyzed by multiple linear regression with SPP version 25; whilst the vulnerability index to season variability was analyzed using Livelihood Vulnerability Index (LVI) method. The results show that income of fishers in east season is higher than in west season. Income differences between east season and west season were $34 \%, 14 \%$ and $16 \%$ for fishing line group, net fishing group and both fishing line and net fishing group, respectively. Determinant factors were day of fishing, distance of fishing area, fishing depth, days at sea, experience, wave height, wind velocity, and rainfall. Days at sea was the most significant factor. LVI analysis shows that vulnerability levels of all fishing groups were vulnerable with LVI scale between 0,28 and 0,31. Results also show that 
should the LVI scale be higher, the group of fishers would become vulnerable to season variability; hence, income of the fishers would be lower than other groups of fishers. Assessment on five capitals (social, economic, human, physical, and natural capital) needs to be supported to enhance the resilience level of the fishers group.

Keywords: Season variability, vulnerability index, income, group of fishers

\section{PENDAHULUAN}

Masyarakat pesisir umumnya menggantungkan hidupnya pada alam sehingga ekosistem pesisir dan laut menjadi sumber mata pencahariannya, seperti bidang perikanan tangkap dan wisata. Kegiatan nelayan pada level produksi hinggapemasaran hasil tangkapan akan dihadapkan dengan berbagai persoalan yang diakibatkan oleh karakteristik lingkungan yang penuh ketidakpastian. Musim adalah salah satu faktor yang dapat mempengaruhi ketidakpastian kehidupan nelayan sebab usaha perikanan sangat tergantung pada musim. Hal tersebut menyebabkan masyarakat pesisir sangat rentan terhadap perubahan musim yang terjadi di Kabupaten Lumajang (Wahyono et al., 2014).

Variabilitas musim adalah perubahan musim terjadi karena diakibatkan adanya revolusi bumi. Musim timur ditandai dengan suhu yang meningkat, sedangkan musim barat ditandai dengan suhu yang menurun. Variabilitas musim mengakibatkan terjadinya pola pergeseran musim barat ataupun musim timur. Nelayan tidak memiliki pedoman menentukan musim melaut. Musim barat identik dengan dengan musim ombak besar, sehingga mereka tidak bisa melakukan penangkapan ikan di laut (Wahyono et al., 2014). Musim barat biasanya terjadi pada bulan Oktober hingga Maret, pada bulan tersebut terjadi musim penghujan di seluruh wilayah Indonesia dengan curah hujan tinggi yang dapat berdampak pada hasil tangkapan perikanan menjadi berkurang dikarenakan cuaca buruk di tengah laut seperti gelombang di laut menjadi tinggi akibat dari arus dan angin di sekitar laut membuat ikan berenang agak dalam menghindari dari tumpahan air hujan yang tawar. Musim timur biasanya terjadi pada bulan April hingga September, dimana bulan ini terjadi musim kemarau dimana seluruh daerah di Indonesia mengalami dampak dari gelombang panas yang dirasa sehingga musim kemarau berdampak jumlah hasil tangkapan ikan semakin banyak atau bertambah dikarenakan sirkulasi udara disekitar laut dan cuaca yang baik di musim kemarau dengan gelombang dilaut tidak begitu tinggi membuat aktivitas nelayan menjadi mudah mencari ikan (Amri, 2017; Khalfianur et al., 2017; Kuswanto et al., 2017; Mulyadi et al., 2015; Nurdin et al., 2018; Rahman et al., 2019; Sultan, 2018).

Ketidakpastian tersebut akan menyebabkan jumlah hari melaut dan perolehan hasil tangkapan dalam setiap kali melaut (fishing trip) menjadi tidak menentu yang akhirnya dapat mempengaruhi besaran pendapatan nelayan (Rahim, (2011); Rahman et al., 2019; Wahyuni \& Zakaria, 2019; Syariah \& Asruddin, 2008; Vibriyanti, 2019). Resiko guncangan pada sistem penghidupan (livelihood system) yang tidak menentu akibat adanya variabilitias musim menjadikan kondisi nelayan menjadi semakin rentan (Alam, 2017; Hahn et al., 2009; Hastanti \& Purwanto, 2019; Hoque et al., 2019; Huong et al., 2019; Zhang et al., 2019). Tujuan dari penelitian ini untuk mengestimasi besar pendapatan, menganalisis faktor-faktor yang mempengaruhi besarnya pendapatan, serta kerentanan nelayan dalam menghadapi variabilitas musim di Pantai Dampar, Kabupaten Lumajang. Hasil penelitian ini diharapkan sebagai bentuk informasi dalam hal besarnya pendapatan nelayan dan kerentanan pendapatan kelompok nelayan karena adanya variabilitas musim.

\section{METODOLOGI}

Penelitian dilakukan pada Kelompok Usaha Bersama Nelayan (KUBN) Dampar yang berada di Pantai Dampar, Kabupaten Lumajang. Metode penelitian menggunakan metode kuantitatif guna menganalisis besaran pendapatan dan nilai kerentanan kelompok nelayan. Analisis untuk mengetahui pendapatan kelompok nelayan diperoleh dari selisih antara penerimaan total dengan total biaya operasional. Faktor-faktor penentu besar pendapatan kelompok nelayan dapat diketahui dengan menggunakan analisis regresi linear berganda menggunakan SPSS versi 25. Analisis dan perhitungan indeks kerentanan pendapatan nelayan Dampar dengan metode Livelihood Vulnerability Index (LVI). Metode 
Livelihood Vulnerability Index (LVI) adalah metode untuk menilai tingkat kerentanan system penghidupan. Metode ini mengukur kerenatanan penghidupan dari berbagai aspek diantaranya adalah katagori kapasitas adaptif (sosio-demografi, strategi rumah tangga nelayan, jejaring sosial), kategori sensitivitas (pangan, kesehatan, aset), kategori keterpaparan (bencana alam, dan musim). Akan tetapi metode ini juga harus menyesuaikan dengan kondisi lokasi penelitian terkait banyanknya parameter yang harus diukur (Hahn et al., 2009; Zhang et al., 2019).

\section{Lokasi dan Waktu Penelitian}

Penelitian dilakukan pada bulan Maret-Juli 2020 di Pantai Dampar, Dusun Dampar, Desa Bades, Kecamatan Pasirian, Kabupaten Lumajang. Titik koordinat pada lokasi penelitian yaitu -8.2894666 LS dan 113.0704985 BT. Lokasi penelitian dapat dilihat dalam Gambar 1.

\section{Jenis dan Metode Pengambilan Data}

Jenis data yang dikumpulkan dalam penelitian ini adalah data primer dan sekunder. Data primer meliputi kuisioner penelitian mengenai identitas responden, jenis pekerjaan, data pendapatan, dan data lainnya yang terkait dengan tujuan penelitian. Data sekunder yang dikumpulkan berupa data potensi perikanan di lokasi penelitian, laporan tahunan Dinas Perikanan Lumajang, dan hasil penelitian terdahulu yang terkait. Sumber data sekunder diperoleh dari berbagai instansi seperti Badan Pusat Statistik Lumajang, Dinas Perikanan Kabupaten Lumajang dan penelusuran literatur hasil penelitian. Metode pengambilan data berupa kuisioner dengan memberikan seperangkat pertanyaan kepada responden penelitian sebagai sumber datanya.

Mengukur besaran sampel yang akan diteliti dengan menggunakan rumus Slovin. Rumus ini mampu untuk mengukur besaran sampel yang akan diteliti. Besaran sampel yang akan diteliti yaitu menggunakan persamaan (1) atau rumus Slovin (Usman \& Setiady, 2008).

Keterangan/Remark:

$\mathrm{n} \quad=$ Jumlah Sampel/sample amount

$\mathrm{N} \quad=$ Jumlah Populasi/population amount

e $\quad=$ Besarnya kesalahan, dalam penelitian ini $(5 \%) /$ Margin of error (5\%)

$$
\mathrm{n}=\frac{N}{1+N(e)^{2}}
$$

Berdasarkan persamaan 1, diperoleh sampel dalam penelitian ini yaitu 66 orang dari total nelayan sebanyak 78 orang yang terbagi menjadi 4 KUBN yakni Langgeng samudera, Laut Biru, Samudera Abadi, dan Mina Samudera. Sampel penelitian yakni 43 orang kelompok nelayan pancing, 16 orang kelompok nelayan jaring, dan 9 orang kelompok nelayan pancing dan jaring. Responden penelitian diambil dengan cara purposive sampling

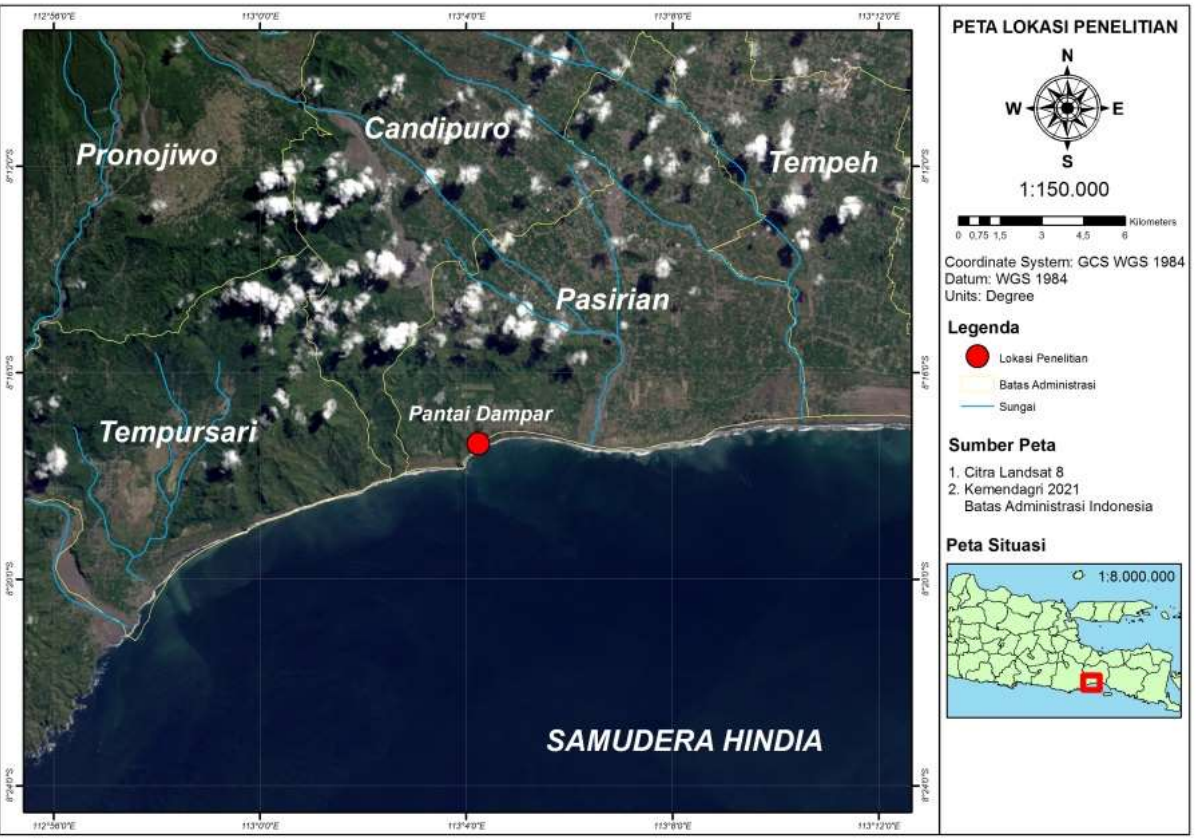

Gambar 1. Peta lokasi penelitian Pantai Dampar Kabupaten Lumajang Figure 1. Map of Research Location of Dampar Beach in Lumajang Regency Sumber: Google Maps, 2021/ Source: Google Maps, 2021 
dengan kriteria domisili di daerah pesisir Dampar yang pekerjaan utamanya nelayan dan tergabung dalam Kelompok Usaha Bersama Nelayan (KUBN) Dampar. Kriteria ini digunakan karena hampir 95 $\%$ responden menggantungkan hidupnya dengan melaut. Pendapatan mereka sangat dipengaruhi oleh banyaknya hasil tangkapan

\section{Metode Analisis}

Analisis yang digunakan dalam penelitian ini adalah Livelihood Vulnerability Index (LVI) yang dikaitkan pengaruhnya dengan besaran pendapatan yang diperoleh dari perhitungan usaha operasional nelayan. Persamaan yang digunakan untuk menghitung besaran pendapatan dengan persamaan (2) (Gaspersz, 2011).

$$
\pi=T R-T C
$$

$$
\begin{aligned}
& \text { Keterangan/Remarks: } \\
& \pi \quad=\text { Pendapatan/income (Rp/ldr) } \\
& \text { TR = Penerimaan total/total acceptance } \\
& (T R=P q \times Q)(R p / / d r) \\
& \text { TC = total biaya operasional/total operational } \\
& \text { costs }(T C=T F C+T V C)(\mathrm{Rp} / / d r) \\
& \text { TFC = total biaya tetap/total fixed costs }(\mathrm{Rp} / / d r) \\
& \text { TVC = total biaya variabel/total } \\
& \text { variable costs }(\mathrm{Rp} / / d r)
\end{aligned}
$$

Penerimaan total adalah banyaknya jumlah hasil tangkapan saat musim barat dan musim timur yang dikonversi dalam harga jual, biaya variabel adalah biaya yang besar kecilnya dipengaruhi berdasarkan produksi biaya BBM, makan, dan tenaga kerja, sedangkan biaya tetap meliputi pembuatan surat-surat kelompok nelayan dan pemeliharaan aset (perawatan perahu, mesin, dan alat tangkap). Biaya variabel terdiri dari biaya BBM, makan, dan tenaga kerja. Faktor-faktor penentu besar pendapatan kelompok nelayan dapat diidentifikasi dengan analisis regresi linear berganda. Analisis regresi linear berganda merupakan suatu model yang mana variabel terikat tergantung pada variabel bebas. (Arum \& Anie, 2012). Persamaan regresi untuk faktor penentu besar pendapatan kelompok nelayan ditunjukkan pada persamaan 3 .

Penggunaan metode analisis regresi linear berganda memerlukan asumsi klasik yang secara statistik harus terpenuhi. Asumsi klasik meliputi asumsi autokorelasi, multikolinearitas, heterokedastisitas, normalitas, linearitas. (Indasari, 2017) Data yang akan dianalisis menggunakan analisis regresi linear berganda yakni berdasarkan jawaban dari responden dengan pertanyaan yang

$$
\begin{aligned}
& Y=\beta_{0}+\beta_{1} X_{1}+\beta_{2} X_{2}+\beta_{3} X_{3}+\beta_{4} X_{4}+\beta_{5} X_{5}+\beta_{6} D_{1} \\
& +\beta_{7} D_{2}+\beta_{8} D_{3}+\varepsilon \ldots \ldots \ldots \ldots \ldots \ldots \ldots \ldots \ldots \ldots \ldots \ldots \ldots \ldots \ldots \ldots \ldots \ldots \ldots \ldots \ldots \ldots \ldots \ldots
\end{aligned}
$$

Keterangan/ Remarks:

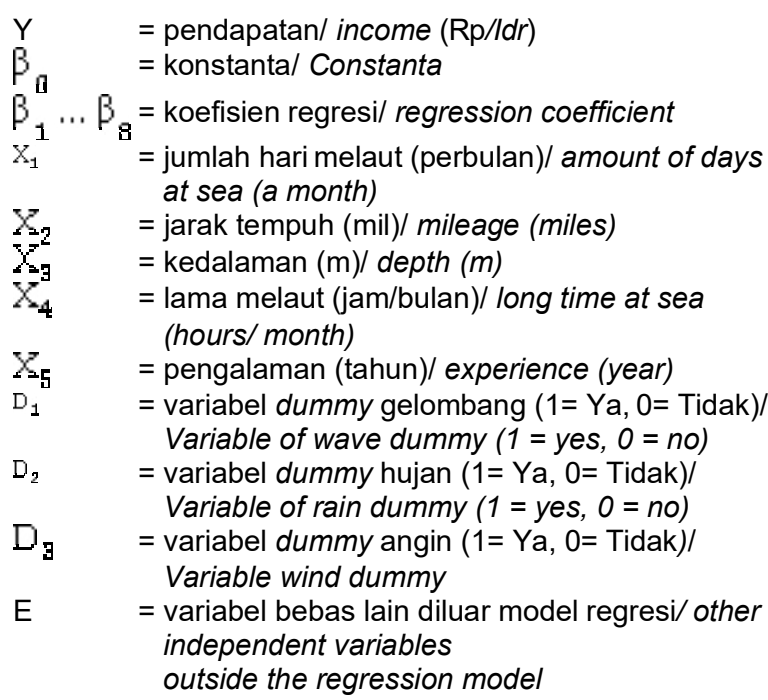

terdapat pada kuisioner penelitian. Pertanyaan tersebut yakni jumlah hari melaut yang dilakukan responden, jarak tempuh, kedalaman, jam kerja melaut, pengalaman melaut atau, serta apakah tetap melaksanakan operasional ketika tinggi gelombang, hujan, dan angin tinggi.

\section{Analisis Tingkat Kerentanan Kelompok Nelayan Pantai Dampar}

Pengukuran LVI dilakukan untuk melihat nilai kerentanan dengan menggunakan persamaan (6), sebelumnya dilakukan perhitungan indeks sub komponen dan nilai komponen utama (sosiodemografi, strategi rumah tangga nelayan, jejaring sosial, pangan, kesehatan, aset, bencana alam, dan musim) dengan menggunakan persamaan (4) \& persamaan (5) (Hahn et al., 2009).

$$
e x_{S_{d}}=\frac{s_{d-}-s_{\min }}{s_{\max }-s_{\min }}
$$

Index $_{S_{d} \text { gan/Remarks: }}$

$$
\begin{aligned}
& S_{d} \quad=\text { indeks sub komponen/sub component index } \\
& S_{\min }=\text { nilai sub komponen/sub component values } \\
& S_{\max }=\text { nilai } \mathrm{minimum} / \text { minimum value } \\
& \text { = nilai maksimum } / \text { maximum value } \\
& \mathrm{Md}=\frac{\sum_{i=1}^{n} \text { indeks sdi }}{n}
\end{aligned}
$$

Keterangan/Remarks:

Md = nilai komponen utama untuk kelompok Dampar/ principal component value for Gampar group

indeks $_{\text {sd }}=$ indeks sub komponen/sub component index

$\mathrm{n} \quad=$ jumlah sub komponen/sub component amount 


$$
\mathrm{LVI}_{\mathrm{d}}=\frac{\sum_{i=1}^{n} w m i \text { Mdi }}{\sum_{i=1}^{n} w m i}
$$

Keterangan/Remarks:

$L_{V I} \quad=$ LVI untuk kelompok nelayan Dampar/ LVI for Dampar fishing group

wmi= bobot sub komponen/sub component weight

Md = nilai komponen untuk kelompok Dampar/ component value for Dampar group

Penentuan skala Livelihood Vulnerability Index (LVI) berdasarkan pada kategori kapasitas adaptif (sosio-demografi, strategi rumah tangga, jejaring sosial), sensitivitas (pangan, kesehatan, aset), dan keterpaparan (bencana alam dan musim). Nilai kapasitas adaptif dan keterpaparan berbanding terbalik dengan kerentanan, sedangkan nilai sensitivitas berbanding lurus dengan kerentanan pada suatu kelompok nelayan. Penentuan indeks kerentanan skala Livelihood Vulnerability Index (LVI) dapat ditunjukkan pada Tabel (1) (Hahn et al., 2009).

Tabel 1. Skala Livelihood Vulnerability Index (LVI), 2020. Table 1. Livelihood Vulnerability Index (LVI) scale, 2020.

\begin{tabular}{|c|c|}
\hline $\begin{array}{l}\text { Skala Livelihood } \\
\text { Vulnerability Index } \\
\text { (LVI)/ Livelihood } \\
\text { Vulnerability Index } \\
\text { (LVI) scale }\end{array}$ & $\begin{array}{l}\text { Kategori/ } \\
\text { category }\end{array}$ \\
\hline $0-0.2$ & $\begin{array}{l}\text { kurang rentan/ } \\
\text { less vulnerable }\end{array}$ \\
\hline $0.21-0.4$ & rentan/vulnerable \\
\hline $0.41-0.5$ & $\begin{array}{l}\text { sangat rentan/ } \\
\text { very vulnerable }\end{array}$ \\
\hline
\end{tabular}

Sumber: Hann, 2009/Source: Hanh, 2009

\section{HASIL DAN PEMBAHASAN}

\section{Karakteristik Responden Penelitian}

Potensi lestari perikanan di Kabupaten Lumajang meliputi perikanan tangkap di perairan Desa Bades merupakan salah satu 10 desa pesisir yang dijadikan sebagai daerah sentra perikanan tangkap. Hal ini dibuktikan pemerintah melalui adanya PPI Dampar yang disiapkan untuk nelayan. Wilayah pantai selatan Kabupaten Lumajang merupakan salah satu penghasil ikan laut tangkapan di propinsi Jawa Timur. Berdasarkan hasil penelitian yang telah dilakukan menunjukkan bahwa umur responden paling banyak antara 41-50 tahun dengan persentase tertinggi 46,4\%. Hal ini menunjukkan bahwa usia nelayan berada pada kategori usia produktif.

Berdasarkan pendidikan terakhir, Pendidikan SD adalah Pendidikan yang paling banyak. Hal ini terjadi karena responden sejak kecil sudah biasa mengikuti orang tuanya untuk mencari ikan sehingga kesempatan untuk bersekolah sangat kecil. Sebanyak 94,2\% pekerjaan utama responden adalah nelayan. Hal ini dikarenakan kehidupan mereka dekat dengan daerah pantai. Pengalaman sebagai nelayan paling banyak yaitu 21-30 tahun dengan 36,2\% karena responden memperoleh pengalaman turun-menurun dari orang tuanya. Pekerjaan sampingan responden yang mendominasi adalah pekebun sebanyak $39,1 \%$ karena mereka bermukim dekat dengan perbukitan.

\section{Variabilitas Musim di Kabupaten Lumajang}

Musim barat yang identik dengan musim hujan, badai, dan ombak. Sebaliknya musim timur identik dengan keadaan laut yang tenang. Adanya variabilitas musim akan berpengaruh terhadap kegiatan operasional perikanan tangkap yang dilakukan oleh nelayan di Pantai Dampar sehingga dapat mempengaruhi jumlah hari melaut. Ketika musim barat, kelompok nelayan cenderung tidak melaut dikarenakan kondisi cuaca yang ekstrim, sebagaimana penelitian terdahulu yang menyatakan bahwa hubungan kecepatan angin dengan hasil tangkapan cenderung saling berlawanan yang artinya ketika kecepatan angin meningkat maka hasil tangkapan akan berkurang sehingga jumlah hari melaut saat musim timur lebih banyak jika dibandingkan dengan musim barat (Amri, 2017; Hahn et al., 2009; Khalfianur et al., 2017; Kuswanto et al., 2017; Nurdin et al., 2018; Rahman et al., 2019). Perbedaan jumlah hari melaut yang dilakukan oleh kelompok nelayan Dampar karena adanya variabilitas dapat dilihat pada Tabel (2)

Berdasarkan Tabel (2) terlihat adanya perbedaan jumlah hari melaut semua kelompok nelayan pada musim barat dan timur. Semua kelompok nelayan mengalami penurunan jumlah hari melaut saat musim barat. Penurunan drastis dirasakan kelompok nelayan pancing dan jaring.

Beberapa faktor yang mempengaruhi variabilitas musim diantaranya curah hujan, tinggi gelombang, dan kecepatan angin. Gambar (2) sampai dengan Gambar (4) menunjukkan hubungan hari melaut kelompok nelayan Pantai Dampar dengan faktor-faktor yang mempengaruhi variabilitas musim yang diperoleh dari BMKG, 2020.

Berdasarkan Gambar (2) dapat diketahui bahwa curah hujan Kabupaten Lumajang selama 
Tabel 2. Perbedaan Jumlah Hari Melaut Akibat Variabilitas Musim Tahun 2019.

Table 2. Difference in the number of days at sea due to the variability of the 2019 season.

\begin{tabular}{lccc}
\hline \multicolumn{1}{c}{$\begin{array}{c}\text { Kelompok Nelayan / } \\
\text { Fishing group }\end{array}$} & $\begin{array}{c}\text { Jumlah Hari melaut (hari)/ } \\
\text { Total Working Hour (days) }\end{array}$ & $\begin{array}{c}\text { Penurunan } \\
\text { (hari)/ } \\
\text { Drop (day) }\end{array}$ \\
\cline { 2 - 4 } $\begin{array}{l}\text { Musim Timur/ } \\
\text { east monsoon }\end{array}$ & $\begin{array}{c}\text { Musim Barat/ } \\
\text { West monsoon }\end{array}$ & 57 \\
Fishing Rod Fishers & 103 & 46 & $(30,98 \%)$ \\
Nelayan Jaring/Cast-net fishers & 101 & 48 & 53 \\
Nelayan Pancing dan Jaring/fishing rods & 107 & 33 & $(28,80 \%)$ \\
and Cast-Net fishers & & 74 \\
Total/amount & & & $(40,22 \%)$ \\
\hline
\end{tabular}

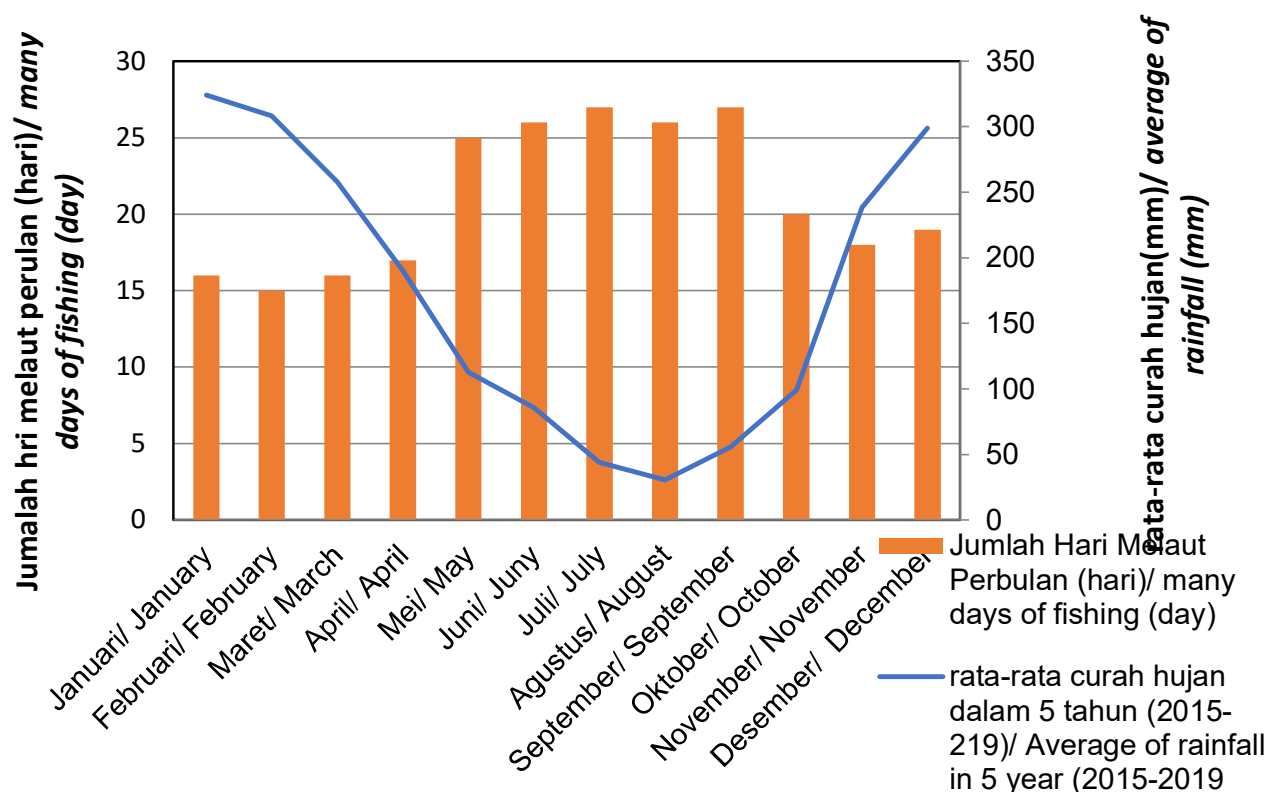

Gambar 2. Hubungan Intensitas rata-rata selama lima tahun terakhir terhadap jumlah hari melaut Kelompok Nelayan di Pantai Dampar, Kabupaten Lumajang.

Figure 2. Correlation of the Rainfall to the number of days at sea for fishers groups in Dampar Beach, Lumajang Regency

lima tahun terakhir tidak dapat diprediksi sehingga pergeseran musim penghujan serta tinggi curah hujan dapat mempengaruhi penurunan hasil tangkapan laut. Hal ini di perkirakan karena suhu permukaan air laut menjadi lebih dingin, sehingga ikan-ikan dominan berada di bawah laut. Seiring dengan penelitian terdahulu (W. Estiningtyas, F. Ramadhani, 2017) yang menyatakan bahwa peningkatan suhu permukaan laut berkaitan dengan meningkatnya curah hujan pada suatu daerah. Ketika curah hujan tinggi, aktivitas melaut yang dilakukan nelayan Pantai Dampar lebih sedikit jika dibandingkan pada musim timur. Musim barat yang identik dengan musim ombak besar, sehingga mereka mengalami penurunan dalam melakukan penangkapan ikan di laut. Pada dasarnya, nelayan mengalami kerugian akibat cuaca yang tidak menentu, namun kerugian yang dialami oleh nelayan bervariasi menurut alat tangkap yang digunakan (Limbong et al., 2017; Sartika et al., 2013; Wahyono et al., 2014).

Terkait tinggi gelombang yang mempengaruhi hari melaut seperti yang ditunjukkan di Gambar (3) terlihat bahwa, tinggi gelombang tidak konstan. Tinggi gelombang tampak berbanding terbalik dengan jumlah hari melaut. Ketika gelombang 


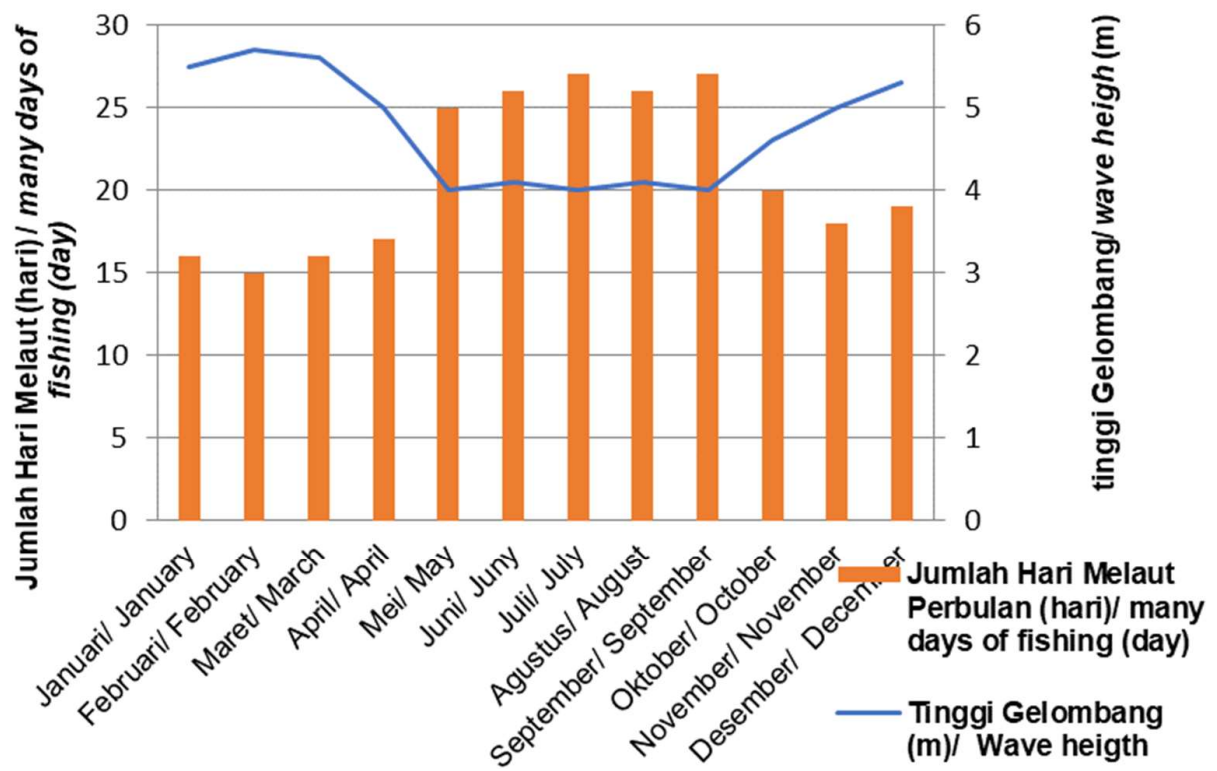

Gambar 3. Hubungan tinggi gelombang terhadap jumlah hari melaut Kelompok Nelayan di Pantai Dampar, Kabupaten Lumajang.

Figure 3. Correlation of wave height to the number of days at sea for fishers groups in Dampar Beach, Lumajang Regency.

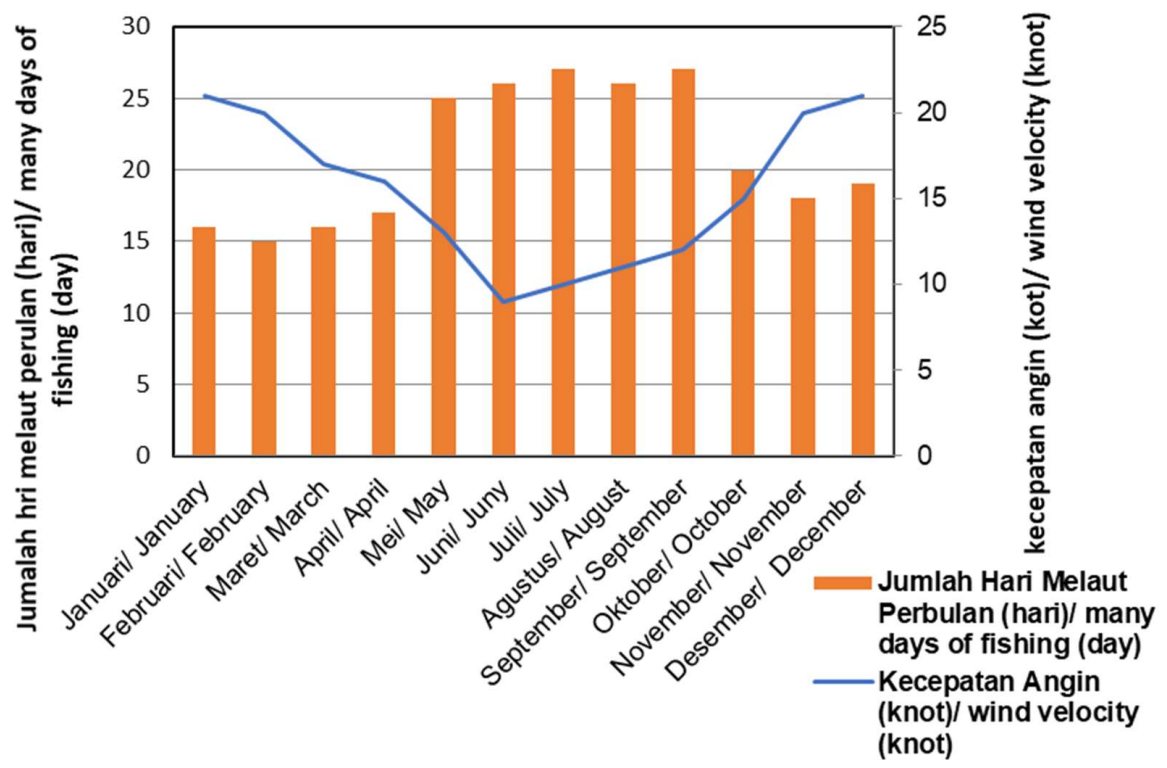

Gambar 4. Hubungan kecepatan angin terhadap jumlah hari melaut Kelompok Nelayan di Pantai Dampar, Kabupaten Lumajang.

Figure 4. Correlation of wind velocity to many days of fishing for fishing group at Dampar Beach, Lumajang Regency.

tinggi, maka jumlah hari melaut menurun, dan begitu sebaliknya. Hal ini dikarenakan gelombang tinggi dapat mempengaruhi keselamatan nelayan (Khalfianur et al., 2017; Limbong et al., 2017; Nurdin et al., 2018; Sartika et al., 2013; Wahyono et al., 2014).

Faktor lain adalah kecepatan angin seperti yang ditunjukkan pada Gambar 4. Hubungan kecepatan angin berbanding terbalik dengan jumlah hari melaut yang dilakukan oleh nelayan di Pantai Dampar. Ketika kecepatan angin tinggi, maka jumlah hari melaut yang dilakukan oleh nelayan di Pantai Dampar akan rendah, begitu juga sebaliknya. Ketika kecepatan angin rendah, maka jumlah hari melaut yang dilakukan oleh nelayan di Pantai Dampar tinggi. 


\section{Pendapatan Nelayan saat Musim Timur dan Barat di Pantai Dampar}

Besarnya pendapatan diperoleh dari selisih penerimaan dengan biaya operasional yang terdiri dari biaya variabel dan biaya tetap. Biaya variabel yang dimaksud adalah biaya BBM, makan, dan tenaga kerja. Biaya makan yakni biaya yang harus dikeluarkan untuk kebutuhan makan sebagai kebutuhan pokok manusia, serta biaya tenaga kerja meliputi biaya untuk tenaga ngojur atau memindahkan perahu untuk diparkir dengan tujuan perahu tidak hanyut saat gelombang tinggi. Sementara biaya tetap merupakan pembuatan surat-surat Kelompok Usaha Bersama Nelayan (KUBN) yang terhimpun di Dinas Perikanan Lumajang dan pemeliharaan aset yaitu perawatan perahu yang meliputi penambalan dan pengecatan perahu, perawatan mesin yaitu ganti oli dan lainnya, serta perawatan alat tangkap seperti menjahit alat tangkap jaring yang telah rusak. Biaya operasional dan pendapatan kelompok nelayan pantai Dampar ditunjukkan Tabel (3) dan Tabel (4).

Berdasarkan Tabel (4) dapat diketahui bahwa persentase pendapatan kelompok nelayan di Pantai Dampar pada musim timur lebih besar daripada musim barat. Hal ini karena dipengaruhi oleh curah hujan, tinggi gelombang, dan kecepatan angin. Selain itu juga terdapat faktor lain yang juga mempengaruhi pendapatan diantaranya curah yaitu faktor pengalaman, faktor jarak tempuh saat melaut, modal dan biaya produksi, dan faktor tenaga kerja (Dahar, 2016).

\section{Faktor-Faktor yang Mempengaruhi Besar Pendapatan Kelompok Nelayan}

Uji normalitas menunjukkan bahwa sampel penelitian yang diambil dari populasi terdistribusi normal. Hal ini ditunjukkan oleh hasil uji Kolmogorovsmirnov sebesar $0,744>0,05$.

Uji autokorelasi menunjukkan bahwa tidak ada gejala autokorelasi. Hal ini ditunjukkan oleh nilai Durbin-Watson sebesar 2,139. Selanjutnya nilai ini akan dibandingkan dengan tabel durbin watson (tabel-dw) dengan $\alpha=5 \%$, jumlah variabel $(k=5)$ dan jumlah sampel $(n=69)$, sehingga diperoleh nilai $D L=1,458$ dan $D U=1,7680$. Hasil uji menunjukkan bahwa $D W>D L$ atau $2,139>1,458$ dan (4-DW)>DU atau 1,861>1,7680. Uji multikolinearitas menunjukkan bahwa tidak ada pelanggaran asumsi multikolinearitas pada model dan hasil pengujian

Tabel 3. Biaya Operasional Kelompok Nelayan di Pantai Dampar (perbulan), 2020.

Table 3. Operational cost of of Fishers Groups at Dampar Beach (monthly), 2020.

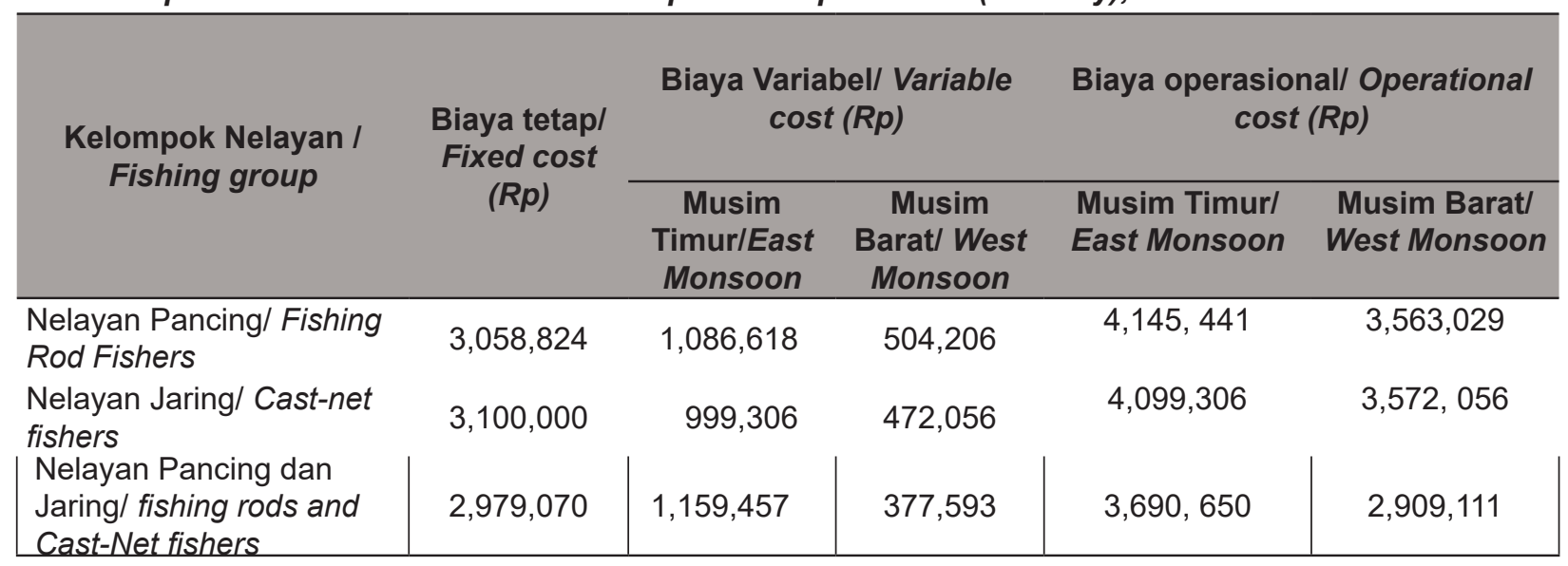

Tabel 4. Pendapatan Kelompok Nelayan di Pantai Dampar (perbulan), 2020.

Table 4. Income of Fishers Groups at Dampar Beach (monthly), 2020.

\begin{tabular}{lcc} 
Kelompok Nelayan /Fishing group & $\begin{array}{c}\text { Musim Timur/East Monsoon } \\
(\boldsymbol{R p})\end{array}$ & $\begin{array}{c}\text { Musim Barat/ West Monsoon } \\
(\boldsymbol{R p})\end{array}$ \\
\hline Nelayan Pancing/ Fishing Rod Fishers & $3,441,000$ & $1,727,000$ \\
& $(67 \%)$ & $(33 \%)$ \\
Nelayan Jaring/ Cast-net fishers & $1,978,000$ & $1,467,000$ \\
& $(57 \%)$ & $(43 \%)$ \\
Nelayan Pancing dan Jaring/ fishing & $5,020,000$ & $3,698,000$ \\
rods and Cast-Net fishers & $(57 \%)$ & $(42 \%)$ \\
\hline
\end{tabular}


dapat dikatakan realibel atau terpercaya. Hal ini ditunjukkan oleh nilai tolerance dan nilai variance inflation factor (VIF). Berdasarkan hasil uji bahwa nilai tolerance untuk seluruh variabel $>0,100$ dan nilai VIF untuk seluruh variabel $<10$.

Uji heteroskedastisitas dengan uji glejser menunjukkan bahwa bahwa tidak terjadi masalah heterokedastisitas. Hal ini ditunjukkan nilai signifikansi (Sig.) untuk seluruh variabel lebih > 0,05 .

Uji linearitas menunjukkan bahwa ada hubungan linear secara signifikan antara variabel independen dan variabel $Y$ sebagai variabel dependen. Hal ini dapat ditunjukkan dengan nilai Deviation from Linearity Sig. Berdasarkan hasil uji pada tiap variabel $\left(X_{1}=0,733 ; X_{2}=0,931 ; X_{3}=\right.$ 0,$719 ; X_{4}=0,760 ; X_{5}=0,794 ; D_{1}=0,894 ; D_{2}=0,764$; $\left.D_{3}=0,834\right)$ menunjukkan nilai Sig. $>0,05$.

Persamaan regresi menunjukkan bahwa model telah memenuhi uji asumsi klasik sehingga model persamaan dalam penelitian ini dianggap baik. Adapun persamaan yang digunakan dalam penelitian ini adalah:

$$
\begin{aligned}
& Y=0,442+0,023 X_{1}+0,045 X_{2}+0,060 X_{3}+ \\
& 0,365 X_{4}+0,094 X_{5}+0,097 D_{1}+0,078 D_{2}+ \\
& 0,400 D_{3}
\end{aligned}
$$

Persamaan regresi linear ini diperoleh dari hasil uji analisis regresi linear berganda dengan variabel yang digunakan pada penelitian ini merujuk persamaan 3. Persamaan regresi tersebut menunjukkan pendapatan nelayan memiliki R-Square sebesar 71,9 persen, artinya bahwa keragaman model pendapatan dapat dijelaskan oleh variabel bebas didalam model sebesar 71,9 persen dan sisanya dijelaskan oleh variabel lainnya yang tidak terdapat di dalam model.

Dari persamaan tersebut dapat dijelaskan sebagai berikut:

- Variabel pertama yaitu jumlah hari melaut $\left(\mathrm{X}_{1}\right)$ yang dilakukan nelayan Pantai Dampar perbulan yaitu memiliki nilai koefisien variabel sebesar 0,023 . Tanda positif memberikan arti bahwa antara jumlah hari melaut memiliki hubungan positif dengan pendapatan nelayan Pantai Dampar yang diperolehnya. Artinya setiap peningkatan jumlah jumlah hari melaut, maka akan meningkatkan pendapatan nelayan Pantai Dampar sebesar 2,3\%.
- Variabel kedua yakni jarak tempuh $\left(\mathrm{X}_{2}\right)$ nelayan Pantai Dampar memiliki koefisien regresi sebesar 0,045 yang memiliki tanda positif, artinya adanya hubungan positif antara jarak tempuh nelayan Pantai Dampar dengan pendapatan yang diperolehnya. Jadi, setiap penambahan jarak penangkapan ikan yang dilakukan nelayan Pantai Dampar menyebabkan peningkatan pendapatan nelayan sebesar $4,5 \%$.

- Variabel ketiga yang mempengaruhi pendapatan yakni kedalaman $\left(\mathrm{X}_{3}\right)$ sebesar 0,060 . Tanda positif mengartikan bahwa antara kedalaman laut dan pendapatan nelayan Pantai Dampar memiliki hubungan yang positif yang artinya setiap penambahan kedalaman laut saat melakukan usaha operasional perikanan tangkap ikan maka akan meningkatkan pendapatan nelayan Pantai Dampar yaitu sebesar 6\%.

- Variabel keempat yaitu jam kerja melaut $\left(\mathrm{X}_{4}\right)$ dengan nilai koefisien regresi sebesar 0,365 dengan tanda positif artinya adanya hubungan positif antara jam kerja melaut dengan pendapatan yang diperoleh oleh nelayan Pantai Dampar. Ketika terjadi peningkatan jam kerja yang dilakukan oleh Nelayan Pantai Dampar, maka akan meningkatkan pendapatan nelayan Pantai Dampar yaitu sebesar 36,5\%.

- Variabel kelima yaitu pengalaman sebagai nelayan $\left(\mathrm{X}_{5}\right)$ dengan nilai koefisien regresi sebesar 0,094 dengan tanda positif yang mengartikan bahwa adanya hubungan antara pengalaman sebagai nelayan yang dimiliki dengan pendapatan yang diperoleh oleh nelayan Pantai Dampar. Artinya setiap penambahan pengalaman sebagai nelayan maka akan meningkatkan pendapatan nelayan Pantai Dampar yaitu 9,4\%.

- Variabel selanjutnya yang mempengaruhi pendapatan nelayan Pantai Dampar yakni dummy tinggi gelombang. Responden menyebutkan gelombang yang tinggi juga menyebabkan responden menunda operasional perikanan tangkap ikan. Koefisien variabel dummy tinggi gelombang yakni 0,097 . Tanda positif mengartikan bahwa adanya hubungan positif antara tinggi gelombang dengan pendapatan yang diperoleh nelayan Pantai Dampar. Responden menganggap 
tingginya gelombang menjadi penyebab perubahan pendapatan dan tetap melakukan operasional perikanan tangkap ikan meskipun gelombang tinggi akan meningkatkan pendapatan sebesar $9,7 \%$. Menurut (Azizi et al., 2017) menyatakan bahwa kondisi perairan dengan gelombang yang tinggi menyebabkan adanya proses pengadukan sedimen yang berdampak pada matinya plankton sebagai sumber makanan bagi ikan yang ada di laut. Kematian ikan menjadikan jumlah makanan ikan berkurang sehingga ikan mencari daerah dengan kondisi wilayah yang memiliki cukup sumber plankton sebagai makanannya. Tingginya gelombang di laut menjadi salah satu penyebab yang mengakibatkan menurunnya jumlah jumlah hari melaut yang dilakukan nelayan dalam melakukan usaha operasional perikanan tangkap ikan menurun. Rendahnya jumlah jumlah hari melaut mengakibatkan pada penerimaan yang dperolehnya juga rendah sehingga menjadikan penurunan yang diperoleh nelayan juga semakin rendah

- Variabel dummy hujan mempengaruhi pendapatan yang diperoleh nelayan Pantai Dampar. Responden menyebutkan bahwa hujan menjadi salah satu penyebab mereka tidak melakukan usaha operasional perikanan tangkap ikan. Koefisien dummy hujan yaitu sebesar 0,078 yang bertanda positif. Tanda positif menunjukkan adanya hubungan positif antara variabel dummy hujan dengan pendapatan yang diperoleh oleh nelayan Pantai Dampar. Responden menganggap curah hujan yang tinggi menjadi penyebab perubahan pendapatan dan tetap melakukan operasional perikanan tangkap ikan meskipun curah hujan tinggi akan meningkatkan pendapatan sebesar $7,8 \%$. Tingginya curah hujan menjadikan salah satu kekhawatiran bagi para nelayan untuk melakukan usaha operasional perikanan tangkap ikan. Menurut ((Azizi et al., 2017)) curah hujan yang tidak dapat diprediksi mengakibatkan pola musim ikan juga berubah. Musim baratan yang identik dengan curah hujan tinggi akan mengakibatkan nelayan tidak melakukan usaha operasional perikanan tangkap. Peningkatan curah hujan yang begitu tinggi disertai dengan kecepatan angin yang tinggi adalah menjadi salah satu penyebab nelayan tidak melaut. Musim hujan mempengaruhi pendapatan yang diterima nelayan akan menurun. Pada musim hujan mengakibatkan suhu air permukaan laut menjadi dingin, sehingga ikan tidak berada di permukaan laut. Akibatnya Ikan mencari kondisi perairan yang lebih hangat dengan ke bawah laut. Kondisi perubahan musim merupakan siklus yang terjadi setiap tahunnya yang tidak dapat diprediksi. Namun, ketika kondisi dalam keadaan sebaliknya, maka ikan laut mudah ditangkap karena ikan banyak yang berada di permukaan laut.

- Variabel dummy angin juga menjadi faktor penentu pendapatan yang diperoleh oleh nelayan Pantai Dampar. Responden menyebutkan bahwa adanya angin kencang menjadi salah satu penyebab mereka tidak melakukan usaha operasional perikanan tangkap ikan. Koefisien dummy angin yaitu sebesar 0,400 yang bertanda positif. Tanda positif menunjukkan adanya hubungan positif antara variabel dummy angin dengan pendapatan yang diperoleh oleh nelayan Pantai Dampar. Responden menganggap angin kencang menjadi penyebab perubahan pendapatan dan tetap melakukan operasional perikanan tangkap ikan, meskipun angin kencang akan meningkatkan pendapatan sebesar $40 \%$.

\section{Kerentanan Kelompok Nelayan Pantai Dampar, Kabupaten Lumajang}

Dampak dari terjadinya varibilitas musim mengakibatkan pendapatan rumah tangga nelayan menjadi fluktuatif, Sehingga membuat pendapatan rumah tangga nelayan menjadi rentan. Ada tiga kategori dan delapan parameter yang diukur meliputi kategori kapasitas adaptif yang meliputi sosio demografi, strategi RT, dan jejaring sosial. Kategori lainnya adalah kategori sensitifitas dan keterpaparan yang meliputi pangan, kesehatan, aset, bencana alam, dan musim. Kelompok nelayan dikatakan kurang rentan dengan skala Livelihood Vulnerability Index (LVI) $(0-0,2)$, kategori rentan $(0,21-0,4)$, dan kategori sangat rentan $(0,41-0,5)$. (Hahn et al., 2009)

Terkait kategori kapasitas adaptif diketahui bahwa kelompok nelayan pancing dan jaring 
$(0,315)$ lebih rentan dibandingkan dengan kelompok nelayan pancing $(0,314)$ maupun kelompok nelayan jaring $(0,253)$, namun hasil analisis tidak menunjukkan perbedaan yang signifikan. Beberapa faktor yang mempengaruhi diantaranya adalah faktor sosio-demografi yang meliputi jumlah anggota keluarga, anggota keluarga yang tidak sekolah dan persentase yang tidak tamat sekolah. Faktor lainnya adalah jejaring sosial yang meliputi rerata RT nelayan yang melakukan pinjaman ke RT nelayan yang lain, rerata RT nelayan yang memberikan pinjaman ke RT nelayan yang lain, dan persentase RT nelayan yang menerima bantuan dari pemerintah pada musim paceklik. Selanjutnya adalah faktor Strategi RT Nelayan yang meliputi rerata jumlah anggota keluarga yang bekerja, rerata anggota keluarga yang bekerja selain nelayan, dan persentase nelayan sebagai pekerjaan utama. Respon dari keseluruhan kelompok nelayan terhadap kerentanan adanya variabilitas musim yakni mereka tidak hanya melaut, tetapi memiliki pekerjaan sampingan dengan memanjat pohon kelapa setelah melaut, menanam sayur dan buah di ladang dekat dengan perbukitan. Beberapa nelayan juga memiliki warung makan dengan mempekerjakan istri dan anaknya untuk menjaga warung. Hal tersebut dilakukan agar mereka mampu bertahan hidup dengan berbagai situasi dan kondisi adanya variabilitas musim

Ditinjau berdasarkan kategori sensitivitas, kelompok nelayan pancing $(0,329)$ lebih rentan dibandingkan dengan kelompok nelayan jaring $(0,248)$ maupun kelompok nelayan pancing dan jaring $(0,288)$. Beberapa faktor yang mempengaruhi tingkat kerentanannya diantaranya adalah faktor pangan yang meliputi persentase RT nelayan yang mengantungkan kebutuhannya dari hasil tangkapan, rerata lama menghidupi RT nelayan dari hasil tangkapan. Faktor lainnya adalah faktor kesehatan yang meliputi persentase RT nelayan yang mengalami gangguan kesehatan, rerata anggota keluarga yang sakit, persentase anggota keluarga nelayan yang sakit kronis, persentase anggota keluarga nelayan yang tidak bekerja/ sekolah karena sakit, rerata jumlah fasilitas kesehatan yang ada di sekitar tempat tinggal nelayan, Rerata waktu yang dibutuhkan untuk menuju ke fasilitas kesehatan, dan persentase RT nelayan yang menerima pelayanan kesehatan dari pemerintah. Selanjutnya adalah Faktor aset yang meliputi rerata RT nelayan yang memiliki aset, dan rerata jumlah aset yang dimiliki.

Ditinjau dari indeks keterpaparan, kelompok nelayan jaring $(0,444)$ lebih rentan dibandingkan dengan kelompok nelayan pancing $(0,239)$ maupun kelompok nelayan pancing dan jaring $(0,234)$. Adapun faktor yang mempengaruhi adalah terkait faktor bencana alam yang meliputi persentase RT nelayan yang menerima peringatan bencana alam, rerata RT nelayan mengalami bencana alam pada 5 tahun terakhir, dan rerata RT nelayan yang terkena dampak bencana alam. Faktor lainnya adalah terkait musim yang meliputi rerata RT nelayan yang mengalami paceklik, rerata musim paceklik dan musim ikan yang diperoleh RT nelayan, dan rerata melaut yang dilakukan oleh RT nelayan.

Gambar (5) menunjukkan nilai Livelihood Vulnerability Index (LVI) semua kelompok nelayan Pantai Dampar, nelayan pancing, nelayan jaring serta nelayan pancing dan jaring.

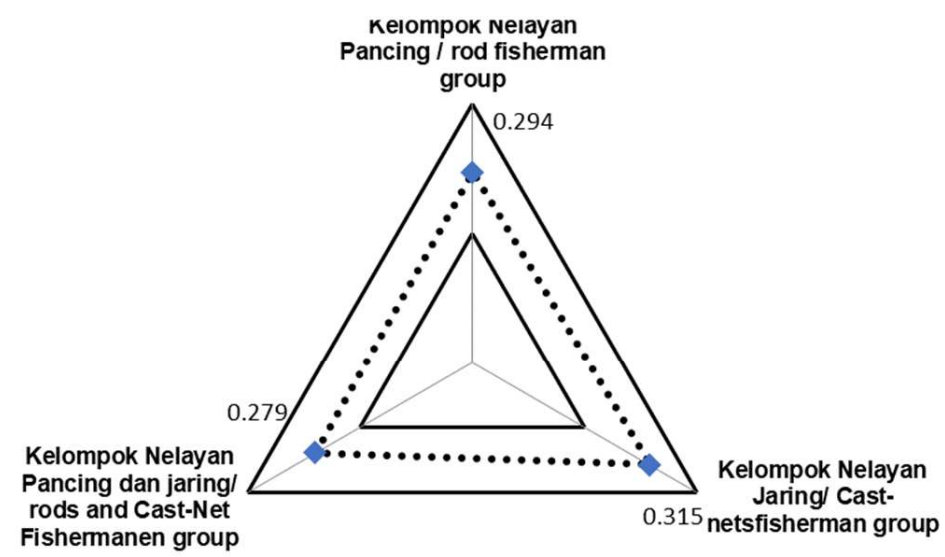

••• Nilai LVI/ LVI Value

Gambar 5. Nilai LVI.

Figure 5. LVI value 
Berdasarkan Gambar (5) menunjukkan indeks kerentanan semua kelompok nelayan pantai Dampar. dimana semua kelompok nelayan berada pada kategori rentan. Indeks kerentanan pada kelompok nelayan jaring diperoleh sebesar $(0,31)$ dan kelompok nelayan pancing dengan indeks sebesar 0,29 serta kelompok nelayan pancing dan jaring $(0,28)$. Hasil tersebut tidak menunjukkan perbedaan yang signifikan, namun demikan akibat variabilitas musim diketahui bahwa kelompok nelayan jaring lebih rentan dibandingkan dengan kelompok pancing maupun kelompok pancing dan jaring.

\section{KESIMPULAN DAN REKOMENDASI KEBIJAKAN}

\section{Kesimpulan}

Variabilitas musim dapat mempengaruhi pendapatan disebabkan oleh berbagai faktor diantaranya curah hujan, tinggi gelombang, dan kecepatan angin. Faktor tersebut yang dapat mempengaruhi jumlah hari melaut yang dilakukan oleh kelompok nelayan sehingga mempengaruhi pendapatan yang mereka peroleh. Pendapatan kelompok nelayan di Pantai Dampar saat musim timur lebih tinggi jika dibandingkan dengan musim barat. Hal ini karena dipengaruhi oleh curah hujan, tinggi gelombang dan kecepatan angin yang cukup tinggi pada musim barat, sehingga berdampak pada jumlah hari melaut. Disamping itu hasil analisis juga menunjukkan terdapat beberapa faktor yang juga mempengaruhi besarnya pendapatan kelompok nelayan di Pantai Dampar meliputi jumlah hari melaut, jarak tempuh, kedalaman, jam kerja melaut, pengalaman sebagai nelayan, variable dummy gelombang, hujan, dan angin. Persentase selisih pendapatan nelayan antara musim timur dan barat sebesar $34 \%$ pada kelompok nelayan pancing, $14 \%$ pada kelompok nelayan jarring, dan $16 \%$ pada kelompok nelayan pancing dan jaring. Sedangkan hasil indeks LVI menunjukkan bahwa semua kelompok nelayan berada dalam kategori rentan akibat perubahan musim. Kelompok nelayan yang paling rentan secara berturut-turut adalah nelayan jaring dengan indeks sebesar $(0,31)$, kelompok nelayan pancing $(0,29)$ serta kelompok nelayan pancing dan jaring $(0,28)$.

\section{Rekomendasi Kebijakan}

Berdasarkan hasil penelitian yang telah dilakukan, diketahui bahwa pendapatan dan kerentanan nelayan pantai dampar dipengaruhi oleh variabilitas musim. Hasil penelitian menunjukkan bahwa pendapatan nelayan pantai Dampar cenderung lebih rendah pada saat musim barat dan sebaliknya meningkat pada musim timur. Tinggi rendahnya pendapatan sangat berdampak pada penghidupan Rumah Tangga nelayan, terutama pada aspek perekonomian sehingga mempengaruhi tingkat kesejahteraan. Upaya agar pendapatan tetap stabil dan bahkan meningkat ketika terjadi variabiitas musim, salah satu solusi adalah menemukan alternatif mata pencaharian lain seperti menciptakan UMKM dan memanfaatkan serta mengembangkan aset yang dimiliki. Terkait tingkat kerentanan, semua kelompok nelayan pantai Dampar berada dalam kategori penghidupan yang rentan akibat variabilitas musim. Dalam hal ini sangat disarankan melakukan berbagai upaya seperti, pembaharuan alat tangkap, metode melaut, bahan bakar melaut, serta pemilihan lokasi dalam melakukan penangkapan ikan.

\section{UCAPAN TERIMA KASIH}

Penulis mengucapkan terima kasih kepada Dinas Perikanan Lumajang, yang telah memberikan ijin penelitian kepada penulis, Kelompok nelayan Dampar yang sudah meluangkan waktunya untuk menjadi responden penelitian, serta temanteman dan semua pihak terkait yang telah banyak membantu dalam penelitian ini.

\section{PERNYATAAN KONTRIBUSI PENULIS}

Dengan inikami menyatakan bahwakontribusi masing-masing penulis terhadap pembuatan karya tulis adalah: Indah Fitriani sebagai kontributor utama, Asri Sawiji dan Noverma Noverma sebagai kontributor anggota. Penulis menyatakan bahwa telah melampirkan surat pernyataan kontribusi penulis.

\section{DAFTAR PUSTAKA}

Alam, G. M. M. (2017). Livelihood Cycle and Vulnerability of Rural Households to Climate Change and Hazards in Bangladesh. Environmental Management, 59(5), 777-791. https://doi. org/10.1007/s00267-017-0826-3

Amri, B. S. \& K. (2017). Pengaruh Anomali Iklim (ENSO dan IOD) terhadap Sebaran Ikan Pedang (Xiphias Gladius) di Samudra Hindia Sebelah Timur. Jurnal Segara, 13(1), 49-63.

Arum, D. N. J., \& Anie. (2012). Statistik deskriptif \& regresi linier berganda dengan pss.

Azizi, A., Kumala Putri, E. I., \& Fahrudin, A. (2017). Analisis Faktor-Faktor Yang Mempengaruhi Perubahan 
Pendapatan Nelayan Akibat Variabilitas Iklim. Jurnal Sosial Ekonomi Kelautan Dan Perikanan, 12(2), 225. https://doi.org/10.15578/jsekp. v12i 2.5320

Dahar, D. (2016). Faktor-Faktor yang Mempengaruhi Pendapatan Nelayan di Desa Pohuwato Timur Kecamatan Marisa Kabupaten Pohuwato. Jurnal Agropolitan, 3, 12-14. https://doi. org/10.1086/690112.

Estiningtyas, W., F. Ramadhani \& E. A. (2017). Analisis Korelasi Curah Hujan dan Suhu Permukaan Laut Wilayah Indonesia, Serta Implikasinya untuk Prakiraan Curah Hujan (Studi Kasus Kabupaten Cilacap). Badan Pengkajian Dan Penerapan Teknologi (BPPT).

Gaspersz, V. (2011). Ekonomi Manajerial (Managerial Economics). 1-742. https://edu.ilmumanajemen. id/wp-content/uploads/2018/12/DOMINICKSALVATORE.pdf

Hahn, M. B., Riederer, A. M., \& Foster, S. O. (2009). The Livelihood Vulnerability Index: A pragmatic approach to assessing risks from climate variability and change-A case study in Mozambique. Global Environmental Change, 19(1), 74-88. https://doi. org/10.1016/j.gloenvcha.2008.11.002

Hastanti, B. W., \& Purwanto, P. (2019). Analisis Keterpaparan, Sensitivitas, dan Kapasitas Adaptasi Masyarakat Terhadap Kekeringan di Dusun Pamor, Kradenan, Grobogan (Analysis of Exposure, Sensitivity and Community Adaptation Capacity to Drought in Pamor Hamlet, Kradenan, Grobogan). Journal of Chemical Information and Modeling, 53(9), 1689-1699.

Hoque, M. Z., Cui, S., Xu, L., Islam, I., Tang, J., \& Ding, S. (2019). Assessing agricultural livelihood vulnerability to climate change in coastal Bangladesh. International Journal of Environmental Research and Public Health, 16(22). https://doi.org/10.3390/ijerph16224552

Huong, N. T. L., Yao, S., \& Fahad, S. (2019). Assessing household livelihood vulnerability to climate change: The case of Northwest Vietnam. Human and Ecological Risk Assessment, 25(5), 1157-1175. https://doi.org/10.1080/10807039.20 18.1460801

Indasari, N. (2017). Faktor-Faktor yang Mempengaruhi Tingkat Pendapatan Nelayan Perahu Motor Tempel di Desa Tamasaju, Kecamatan Galesong Utara, Kabupaten Takalar. Makassar: Universitas Islam Negeri Alaudin Makassar.

Rahim, A. (2011). Analisis Pendapatan Usaha Tangkap Nelayan Dan Faktor-Faktor Yang Mempengaruhinya Di Wilayah Pesisir Pantai Sulawesi Selatan. Jurnal Sosial Ekonomi Kelautan Dan Perikanan, 6(2), 235. https://doi.org/10.15578/ jsekp.v6i2.5776

Khalfianur, W., Niati, C. R., \& Harahap, A. (2017).
Pengaruh Gelombang Laut Terhadap Hasil Tangkapan Nelayan Abstrak Pendahuluan Metodologi Penelitian. Jurnal IImiah Samudra (AKUATIKA), 1(2), 21-25.

Kuswanto, T. D., Syamsuddin, M. L., \& Sunarto. (2017). Hubungan Suhu Permukaan Laut dan Klorofil-a Terhadap Hasil Tangkapan Ikan Tongkol di Teluk Lampung. Jurnal Perikanan Dan Kelautan, VIII(2), 90-102.

Limbong, I., Wiyono, E. S., Yusfiandayani, R., Psp, D., \& Ipb, F. (2017). Faktor-faktor yang Mempengaruhi HAsil Produksi Unit Penangkapan Pukat Cincin di PPN Sibolga, Sumatra Utara. ALBACORE Jurnal Penelitian Perikanan Laut, I(1), 89-97.

Mulyadi, ., Jumarang, M. I., \& Apriansyah, . (2015). Studi Variabilitas Tinggi dan Periode Gelombang Laut Signifikan di Selat Karimata. Positron, 5(1). https://doi.org/10.26418/positron.v5i1.9737

Nurdin, E., Panggabean, A. S., \& Restianingsih, Y. H. (2018). Pengaruh parameter oseanografi terhadap hasil tangkapan armada tonda di sekitar rumpon di Palabuhanratu. Jurnal Penelitian Perikanan Indonesia, 24(2), 117-126.

Rahman, M. A., S., M. L., Agung, M. U. K., \& Sunarto. (2019). Pengaruh Musim Terhadap Kondisi Oseanografi dalam Penentuan Daerah Penangkapan Ikan Cakalang (Katsuwonus pelamis) di Perairan Selatan Jawa Barat. Jurnal Perikanan Dan Kelautan, 10(1), 92-102.

Sartika, S., Sitepu, H., \& Bangun, P. (2013). Analisis Faktor-Faktor Yang Mempengaruhi Hasil Produksi Tangkapan Nelayan di Kecamatan Bilato Kabupaten Gorontalo. Saintia Matematika, 1(5), 445-457.

Sultan. (2018). Pengaruh Angin dan Curah Hujan Terhadap Produksi Nelayan yang Berbasis di Pelabuhan Paotere (The Effect of Wind and Rainfall on Fishers Production Based at the Port of Paotere).

Syariah, N., \& Asruddin. (2008). Analisa Pendapatan Rumah Tangga Nelayan Pancingdi Kawasan Bone Pesisir, Bone Bolango. Akademika Jurnal IImiah Umg, 57-66.

Usman, H., \& Setiady, P. (2008). Metodologi Penelitian Sosial Budaya. In Jakarta: Bumi Aksara. https:// difarepositories.uin-suka.ac.id/152/1/metodologi penelitian sosial.pdf

Vibriyanti, D. (2019). Analisis Deskriptif Faktor Sosial Ekonomi yang Mempengaruhi Pendapatan Rumah Tangga Nelayan Tangkap (Studi Kasus: Kota Kendari). Jurnal Kebijakan Sosial Ekonomi Kelautan Dan Perikanan, 9(1), 69. https://doi. org/10.15578/jksekp.v9i1.7440

Wahyono, A., Imron, M. \& Nadzir, I. (2014). Resiliensi komunitas nelayan dalam menghadapi perubahan iklim: Kasus di Desa Grajagan Pantai , Banyuwangi, Jawa Timur. Masyarakat 
\& Budaya, 16(2), 259-274. https://jmb.lipi.go.id/ index.php/jmb/article/download/17/7.

Wahyuni, S. dan Zakaria, W.A. (2019). Pendapatan Rumah Tangga Nelayan di Pesisir Kota Agung Kabupaten Tanggamus. Jurnal Imu-Imu Agribisnis (Journal of Agribusness Science), 7(4), 521-528.

Zhang, Q., Zhao, X., \& Tang, H. (2019). Vulnerability of communities to climate change: application of the livelihood vulnerability index to an environmentally sensitive region of China. Climate and Development, 11(6), 525-542. https://doi.org/10. 1080/17565529.2018.144280 